\title{
Design and Synthesis of 3-(3-Chloro-4-substituted phenyl)-4-(pyridin-4-yl)-1H- pyrazole-1-carboxamide Derivatives and Their Antiproliferative Activity Against Melanoma Cell Line
}

\author{
Mohammed I. El-Gamal and Chang-Hyun $\mathrm{Oh}^{\dagger, *}$ \\ Department of Biomolecular Science, University of Science and Technology, Daejeon 305-333, Korea \\ ${ }^{\dagger}$ Biomaterials Center, Korea Institute of Science and Technology, Seoul 130-650, Korea. *E-mail: choh@kist.re.kr \\ Received November 22, 2010, Accepted December 28, 2010
}

\begin{abstract}
Design and synthesis of new 3,4-diarylpyrazole-1-carboxamide derivatives are described. Their antiproliferative activity against A375 human melanoma cell line was tested and the effect of substituents on the diarylpyrazole scaffold was investigated. The pharmacological results indicated that most of the synthesized compounds showed moderate activity against A375, compared with Sorafenib. On the other hand, compounds Ia, Ie, IIb, and IIh were more potent than Sorafenib. In addition, compound IIa was equipotent to Sorafenib. Among all of these derivatives, compound IIb which has diethylamino and phenolic moieties showed the most potent antiproliferative activity against A375 human melanoma cell line. Virtual screening was carried out through docking of the most potent compound IIb into the domain of V600E-b-Raf and the binding mode was studied.
\end{abstract}

Key Words : Antiproliferative activity, 1 H-Pyrazole-1-carboxamide, 3,4-Diarylpyrazole, A375, Melanoma

\section{Introduction}

Melanoma is the most aggressive form of skin cancer and is the fastest growing cancer in the United States. ${ }^{1,2}$ Early stage melanoma can be cured surgically. However, melanoma metastasizing to major organs (stage IV) is virtually incurable. ${ }^{1}$ Patients with advanced melanoma have a median survival time of less than one year, and the estimated 5-year survival time is less than $15 \%$. ${ }^{1,3}$ With the incidence of melanoma rapidly rising in the United States and other developed countries, there is an urgent need to develop more effective drugs. ${ }^{4-6}$

The current treatments involve surgical removal of the tumor, immunotherapy, radiotherapy, chemotherapy, various combinations, or the use of new treatments in clinical trials. As for immunotherapy, interferon alfa- $2 \mathrm{~b}$ (Intron-A) ${ }^{7}$ has been approved by both the FDA and EMEA for adjuvant treatment of melanoma patients, and aldesleukin (Proleukin $)^{8,9}$ has been also approved for the treatment of metastatic melanoma in the USA.

There are many promising, potent, and selective antiproliferative agents for treatment of melanoma. Sorafenib ${ }^{10-15}$ is an oral multikinase inhibitor that targets 2 classes of kinases which are known to be involved in both tumor proliferation and angiogenesis. ${ }^{16}$ It inhibits Raf kinases (Raf1 and b-Raf), as well as proangiogenic receptor tyrosine kinases of the PDGFR and VEGFR family. ${ }^{12}$ The antiproliferative activity of Sorafenib against melanoma is assumed to be due to b-Raf inhibition and induction of apoptosis in a caspase-independent manner. ${ }^{17}$ Sorafenib demonstrated high antiproliferative activity against different melanoma xenografts and cell lines, ${ }^{17}$ but not in case of advanced metastatic melanoma (stage IV). ${ }^{16}$ In addition, Sorafenib has been implicated in the development of reversible posterior leukoencephalopathy syndrome and secondary erythrocytosis. ${ }^{18}$ The poor efficiency of Sorafenib in case advanced metastatic melanoma and its side effects encourage the search for new antiproliferative compounds for treatment of melanoma.

Antiproliferative agents with 3,4-diarylpyrazole scaffold targeting b-Raf kinase that can be efficient for treatment of melanoma have been identified. ${ }^{19,20}$ In the present study, compounds $\mathrm{A}^{19}$ and $\mathrm{B}^{21}$ (Fig. 1) were considered as the parent compounds for design of our target compounds. In our efforts in order to develop new antiproliferative agents for treatment of melanoma, we designed and synthesized new 3,4-diarylpyrazole derivatives possessing an amide moiety at position 1 of the pyrazole ring. The synthesized compounds Ia-i and IIa-i were designed by replacement of

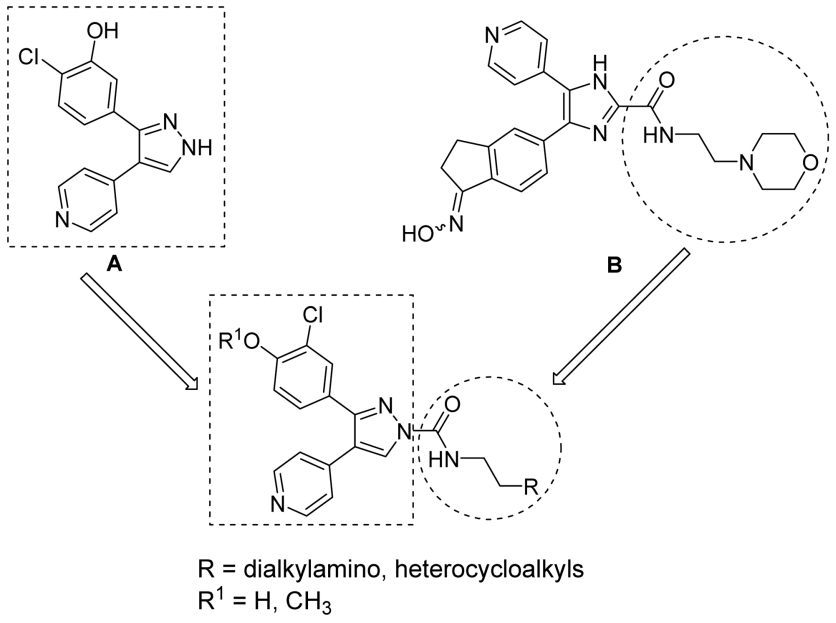

Figure 1. Structures of parent compounds $\mathrm{A}$ and $\mathrm{B}$, and target compounds. 
Table 1. Antiproliferative activity of methoxy compounds Ia-i against A375P cell line

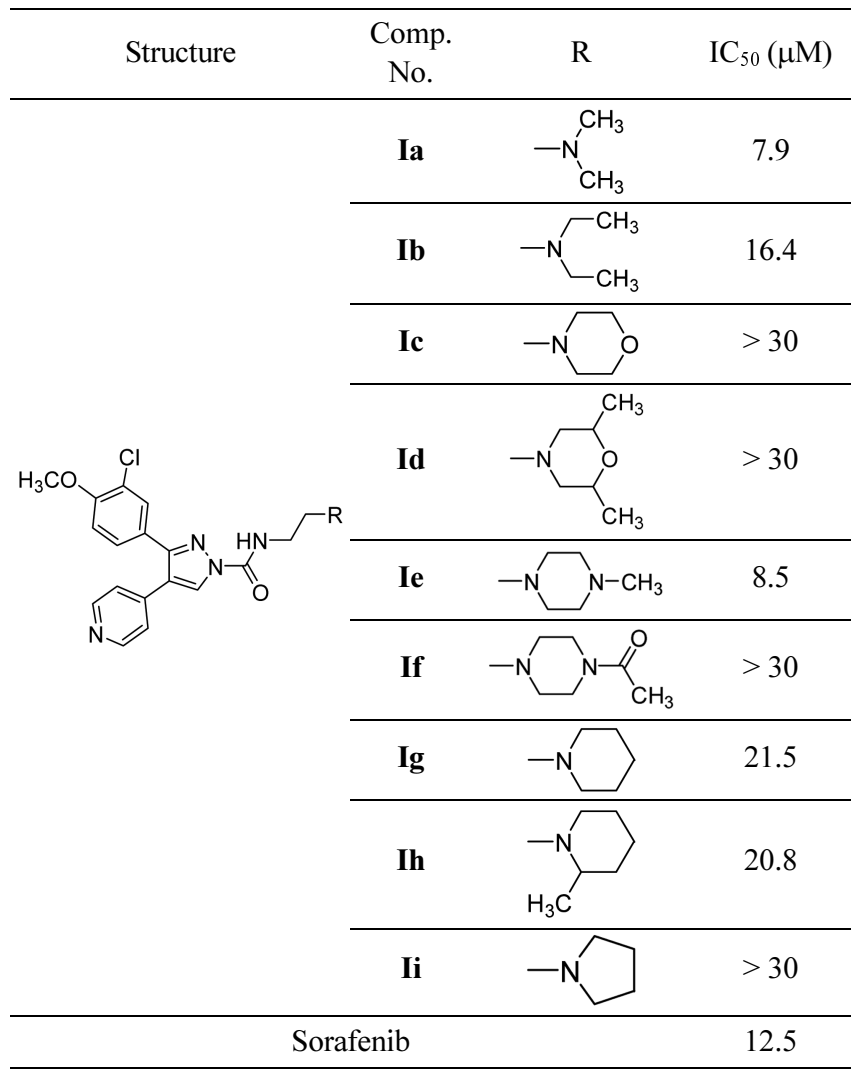

the phenolic ring of A with 3-chloro-4-(methoxy/hydroxyl) substituted phenyl ring and introduction of derivatives of the carboxamide side chain of compound B into position 1 of the pyrazole ring. The phenolic hydroxy group was retained in compounds IIa-i and modified into methoxy group in compounds Ia-i in order to examine its effect on the activity (Fig. 1). Herein, we report the synthesis and antiproliferative activity against A375 human melanoma cell line of these compounds. In silico and molecular docking studies are also reported.

\section{Results and Discussion}

Chemistry. 3,4-Diarylpyrazole derivatives Ia-i and IIa-i with amide moiety at position 1 of the pyrazole ring were prepared according to the sequence of reactions shown in Scheme 1. Heating 3,4-dichlorobenzoic acid (1) with three molar equivalents of sodium methoxide in hexamethylphosphoramide (HMPA) followed by acidification with $\mathrm{HCl}$ gave 3-chloro-4-methoxybenzoic acid (2), which upon esterification with methanol in the presence of acetyl chloride afforded the corresponding methyl ester 3 . The pyridyl derivative $\mathbf{4}$ was obtained by treatment of $\mathbf{3}$ with 4picoline in the presence of lithium bis(trimethylsilyl)amide (LHMDS). Cyclization to the pyrazole compound $\mathbf{5}$ was carried out by treatment of $\mathbf{4}$ with dimethylformamide dimethyl acetal (DMF-DMA), and subsequent treatment with hydrazine monohydrate. Interaction of $\mathbf{5}$ with phenyl chloro-
Table 2. Antiproliferative activity of hydroxy compounds IIa-i against A375P cell line

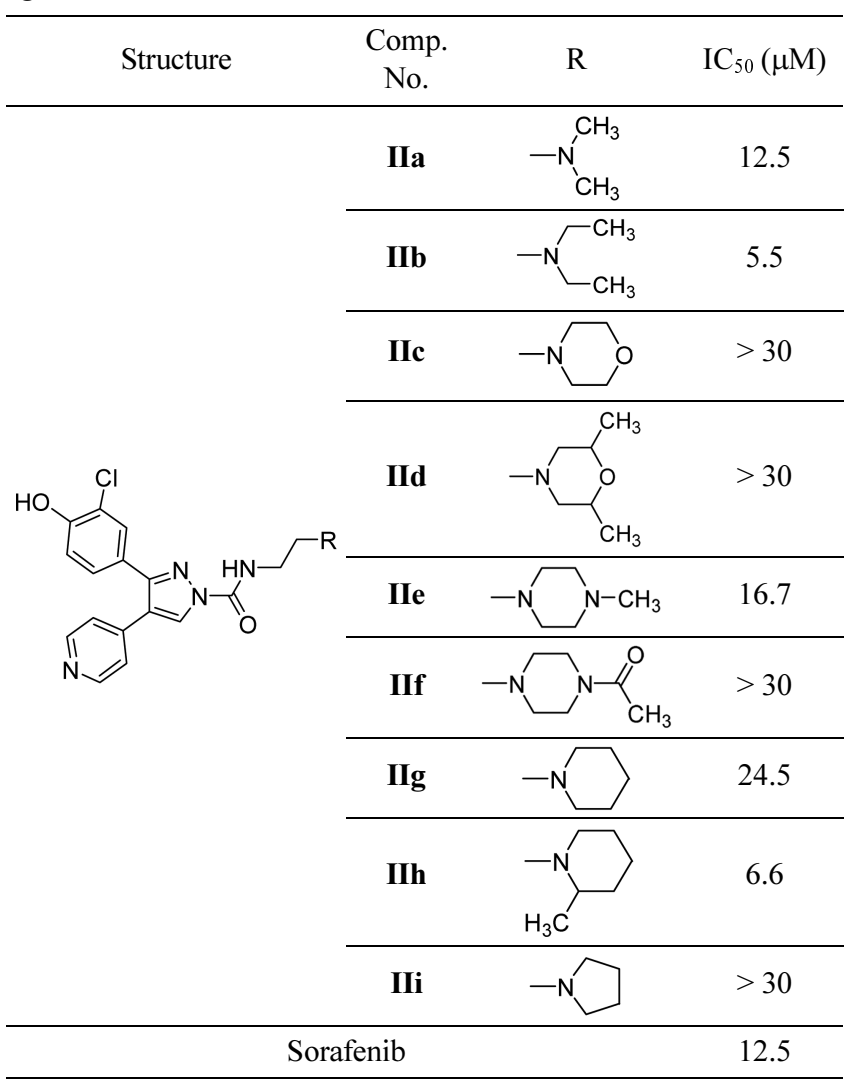

formate in the presence of triethylamine gave a mixture of pyrazole-2-carboxylate derivative $\mathbf{6}$ and pyrazole-1-carboxylate derivative 7 in an approximate ratio of 1:5. The mixture was then reacted with the appropriate ethanamines to furnish the target methoxy compounds Ia-i in combination with their regioisomers 8. Compounds Ia-i with lower $R_{f}$ values on TLC were obtained in the pure form after purification by flash column chromatography. Demethylation of the methoxy group of Ia-i using boron trifluoridemethyl sulfide complex afforded the corresponding hydroxy derivatives IIa-i.

Antiproliferative Activity and Discussion. The antiproliferative activity of the synthesized compounds against A375 human melanoma cell line was tested. The ability of the $1 H$-pyrazole-1-carboxamide derivatives to inhibit the growth of A375 cell line is summarized in Tables 1 and 2. The results are expressed as $\mathrm{IC}_{50}$ values. Sorafenib was selected as a reference standard.

As Listed in Tables 1 and 2, Most of the Compounds showed moderate activity, while compounds Ia, Ie, IIb, and IIh having $\mathrm{IC}_{50}$ values ranging from 5.5 to $8.5 \mu \mathrm{M}$ were more potent than Sorafenib $\left(\mathrm{IC}_{50}=12.5 \mu \mathrm{M}\right)$. In addition, compound IIa exhibited similar potency to that of Sorafenib. Compounds Ia and Ie possess a methoxy group on the benzene ring while compounds IIa, IIb, and IIh possess a hydroxy group. In addition, the $\mathrm{R}$ moiety of compounds Ia and IIa is dimethylamino while the R moieties of compounds Ie, IIb, and IIh are $N$-methylpiperazinyl, di- 

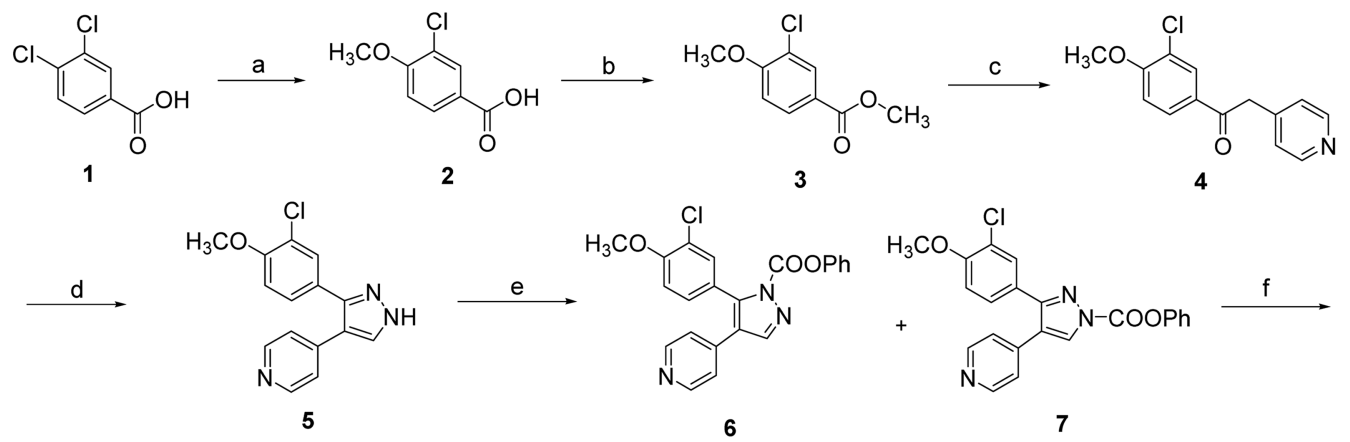

2

3

$$
4
$$
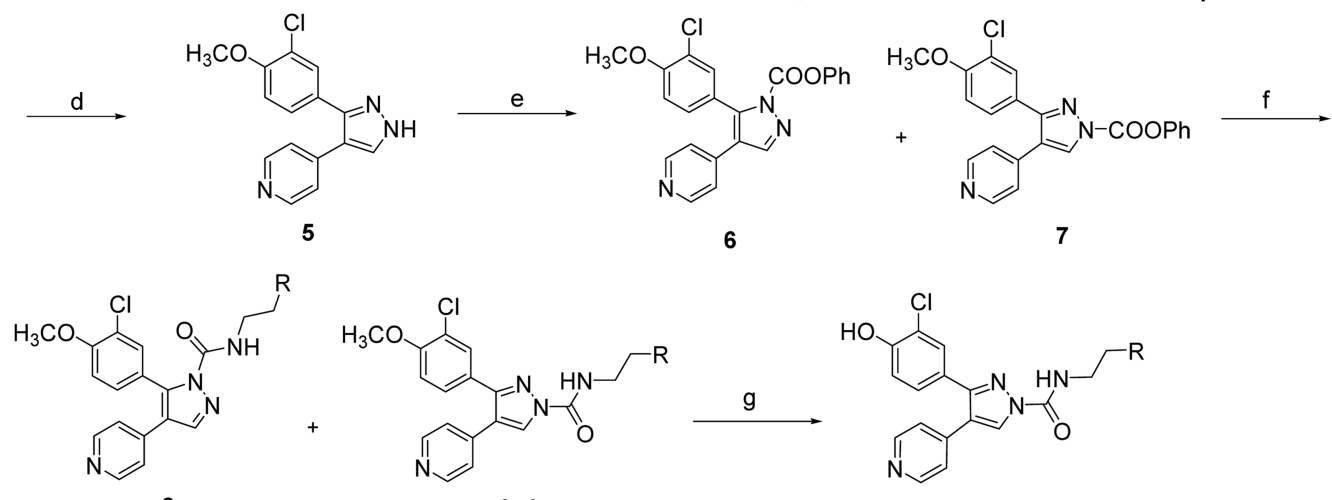

8
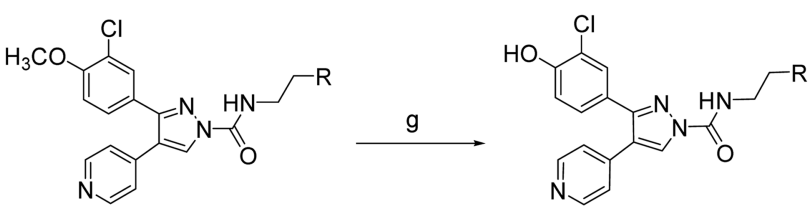

la-i

Ila-i

Scheme 1. Synthesis of the target compounds Ia-i and IIa-i.

Reagents and conditions: (a) sodium methoxide, HMPA, 115-120 ${ }^{\circ} \mathrm{C}, 15 \mathrm{~h}$; (b) acetyl chloride, MeOH; (c) 4-picoline, LHMDS, THF; (d) (i) DMF-DMA, (ii) hydrazine monohydrate, EtOH; (e) phenyl chloroformate, TEA, THF; (f) substituted ethanamines, $\mathrm{K}_{2} \mathrm{CO}_{3}, \mathrm{CH}_{2} \mathrm{Cl}_{2} ;(\mathrm{g})$ $\mathrm{BF}_{3} \cdot \mathrm{Me}_{2} \mathrm{~S}, \mathrm{CH}_{2} \mathrm{Cl}_{2}$.

ethylamino, and 2-methylpiperidinyl, respectively.

The methoxy compounds Ia, Ie, and Ig were more potent than the corresponding hydroxy derivatives IIa, IIe, and IIg. On the other hand, compounds IIb and IIh with hydroxyl group were more potent than the corresponding methoxy compounds Ib and $\mathbf{I h}$. The most potent derivative of this series is a hydroxy compound IIb.

The effect of the terminal substituents of the tail at position 1 of the pyrazole ring was also investigated. The newly synthesized compounds with morpholine, 2,6-dimethylmorpholine, $N$-acetylpiperazine, and pyrrolidine moieties showed diminished activity. We can conclude that these moieties are unfavorable for antiproliferative activity against melanoma of this series of compounds. Upon comparing the activity of the piperazinyl derivatives, it was found that the $\mathrm{N}$-methyl derivatives (Ie and IIe) were more potent than that of $N$-acetyl derivatives (If and IIf). These results may be rationalized by the steric and/or electronic effects of the acetyl group, compared with the methyl group. Introduction of a methyl group on the piperidine ring (compounds $\mathbf{I}$ and IIh) enhanced the activity compared with unsubstituted piperidine ring (compounds Ig and IIg). On the other hand, introduction of two methyl groups on the morpholine ring (compounds Id and IId) did not alter the activity, compared with derivatives having unsubstituted morpholine ring (compounds Ic and IIc).

In conclusion, a series of 3-(3-chloro-4-substituted phenyl)4-(pyridin-4-yl)-1 $H$-pyrazole-1-carboxamide derivatives was designed and synthesized. Among all of these derivatives, compound IIb having substituted $p$-hydroxyphenyl and diethylamino moieties showed the most potent antiproliferative activity against A375 human melanoma cell line. It can be concluded that these moieties are optimal for antiproliferative activity of this series of compounds. Further modification of these compounds in order to improve their potency is currently in progress.

Lipinski's Rule of Five and Drug-Likeness Profile. In this work, the bioavailability of the most active compounds Ia, Ie, IIa, IIb and IIh was assessed using ADME (absorption, distribution, metabolism, and elimination) prediction methods. In particular, we calculated the compliance of compounds to the Lipinski's rule of five. ${ }^{22}$ This approach has been widely used as a filter for substances that would likely be further developed in drug design programs. In addition, we calculated the total polar surface area (TPSA) since it is another key property that has been linked to drug bioavailability. Thus, passively absorbed molecules with a TPSA $>140$ are thought to have low oral bioavailability. ${ }^{23}$ Molecules violating more than one of these rules may have problems with bioavailability. Predictions of ADME properties for the studied compounds are given in Table 3. The results showed that all the potent compounds comply with these rules and even Sorafenib showed no violation. Theoretically, these compounds should present good passive oral absorption and differences in their bioactivity can not be attributed to this property.

Currently, there are many approaches to assess a compound drug-likeness based on topological descriptors, fingerprints of molecular drug-likeness structure keys or other properties such as $c \log \mathrm{P}$ and molecular weight. ${ }^{24}$ In this work, we used the Osiris program ${ }^{25}$ for calculating the fragment-based drug likeness of the most potent compounds and comparing them with Sorafenib. Interestingly, all the potent compounds Ia, Ie, IIa, IIb, and IIh demonstrated better drug-likeness values (from 9.55 to 3.51) than Sorafenib $(-4.2)$. In this study we also examined the drug-score. The results showed that the five potent compounds demonstrated higher drug-score values than Sorafenib (Fig. 2). Moreover, 
Table 3. Solubility and calculated Lipinski's rule of five for the most potent compounds over human melanoma (A375P) cell line

\begin{tabular}{|c|c|c|c|c|c|c|c|c|}
\hline \multirow{2}{*}{ Compd. No. } & \multirow{2}{*}{$\mathrm{IC}_{50}{ }^{a}$} & \multirow{2}{*}{$\log S^{b}$} & \multicolumn{6}{|c|}{ Parameter } \\
\hline & & & $c \log \mathrm{P}^{c}$ & $\mathrm{TPSA}^{d}$ & $\mathrm{MW}^{e}$ & $n \mathrm{ON}^{f}$ & $n \mathrm{OHNH}^{g}$ & $n$ violations \\
\hline Ia & 7.9 & -4.26 & 2.68 & 72.29 & 399.88 & 7 & 1 & 0 \\
\hline Ie & 8.5 & -3.83 & 2.72 & 75.53 & 454.96 & 8 & 1 & 0 \\
\hline IIa & 12.5 & -3.95 & 2.49 & 83.28 & 385.86 & 7 & 2 & 0 \\
\hline IIb & 5.5 & -4.55 & 3.36 & 83.28 & 413.91 & 7 & 2 & 0 \\
\hline IIh & 6.6 & -5.28 & 3.90 & 83.28 & 439.95 & 7 & 2 & 0 \\
\hline Sorafenib & 12.5 & -6.69 & 4.27 & 92.35 & 464.82 & 7 & 3 & 0 \\
\hline
\end{tabular}

${ }^{a}$ Data taken from Tables 1 and $2 .{ }^{b}$ Solubility parameter. ${ }^{c}$ Calculated lipophilicity. ${ }^{d}$ Total polar surface area $\left(\AA^{2}\right) .{ }^{e}$ Molecular weight. ${ }^{f}$ Number of hydrogen bond acceptor. ${ }^{g}$ Number of hydrogen bond donor.

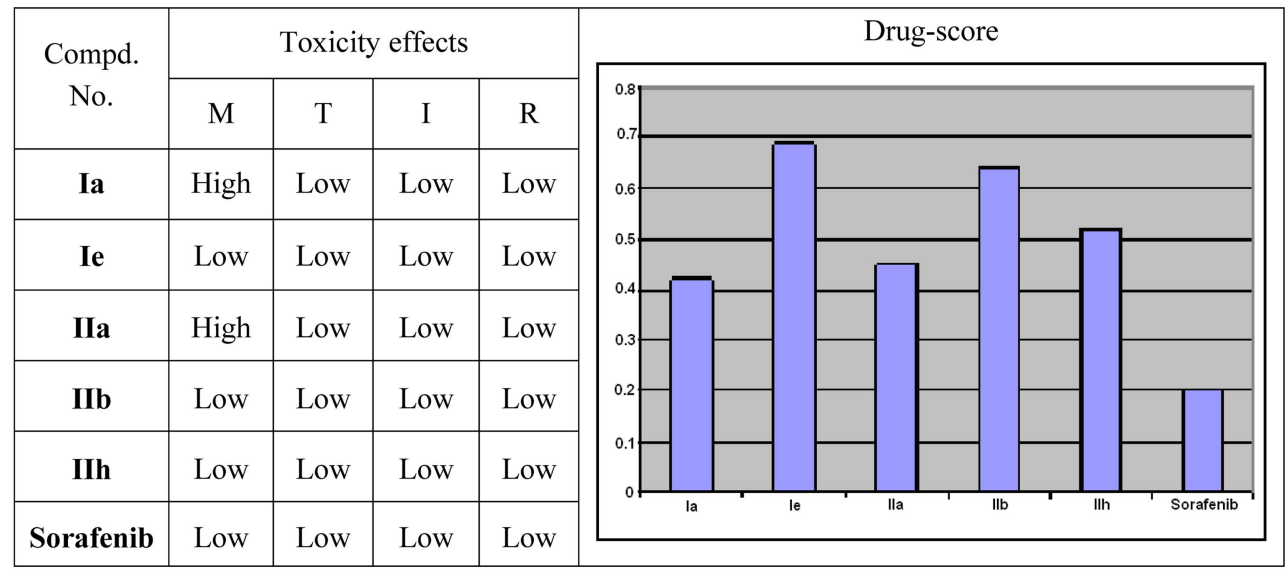

Figure 2. In silico toxicity risks (left panel) and drug-score (right panel) of Sorafenib and the most potent antiproliferative pyrazole derivatives over melanoma cancer ( $\mathrm{M}$, mutagenic; $\mathrm{T}$, tumorigenic; I, irritant; $\mathrm{R}$, reproductive).

we used the Osiris program for prediction of the overall toxicity of the most active derivatives as it may point to the presence of some fragments generally responsible for the mutagenic, tumorigenic, irritant, or reproductive effects in these molecules. Unfortunately, compounds Ia and IIa showed high in silico mutagenic risk because of the dimethylamino moiety. On the contrary, compounds Ie, IIb, and IIh presented a low in silico toxicity risk profile, similar to Sorafenib (Fig. 2). These theoretical data reinforced the cytotoxicity experimental data described in this work pointing these compounds as lead compounds with low toxicity risk profile.

Molecular Docking. The level of antiproliferative activity of the synthesized compounds over melanoma cells, in which b-Raf kinase is over-expressed and mutated, promoted us to perform molecular docking into the domain of b-Raf kinase. Compound IIb which is the most potent derivative of this series was used for docking study as a representative example. All calculations were performed using MOE 2008.10 software $^{26}$ installed on 2.0G Core 2 Duo. The crystal structure of V600E-b-Raf Kinase in complex with PLX4032 (PDB code: 3OG7) was obtained from protein data bank (PDB). ${ }^{27}$ The automated docking program of MOE 2008.10 was used for docking of IIb into the domain of V600E-b-Raf kinase. The complex was energyminimized with a MMFF94 $x$ force-field ${ }^{28}$ till the gradient convergence $0.01 \mathrm{kcal} / \mathrm{mol}$ was reached. The docking study has revealed that the ligand has bound in the active site of one of the protomers in the protein dimer through the formation of three strong hydrogen bonds between the binding site and the ligand. These hydrogen bonds have been formed between the phenolic hydroxyl hydrogen atom and Gln-B559 (1.63 \&); carboxamide oxygen atom and GlnB530 (1.86 A); and diethylamino nitrogen atom and LysB591 (1.73 A). Figures 3 and 4 demonstrate the binding model of the most potent compound IIb with the binding site of V600E-b-Raf. The results of this molecular docking study can support the postulation that our active compounds may act on the same enzyme target, b-Raf, whose inhibition can lead to antiproliferative effect against melanoma cells.

\section{Experimental}

Chemistry. All melting points were obtained on a Walden Precision Apparatus Electrothermal 9300 apparatus and are uncorrected. Mass spectra (MS) were taken in ESI mode on a Waters 3100 Mass Detecter (Waters, Milford, MA, USA). Nuclear magnetic resonance (NMR) spectroscopy was performed using a Bruker ARX-400, $400 \mathrm{MHz}$ spectrometers (Bruker Bioscience, Billerica, MA, USA) with TMS as an internal standard. IR spectra ( $\mathrm{KBr}$ disks) were recorded with a Bruker FT-IR instrument (Bruker 

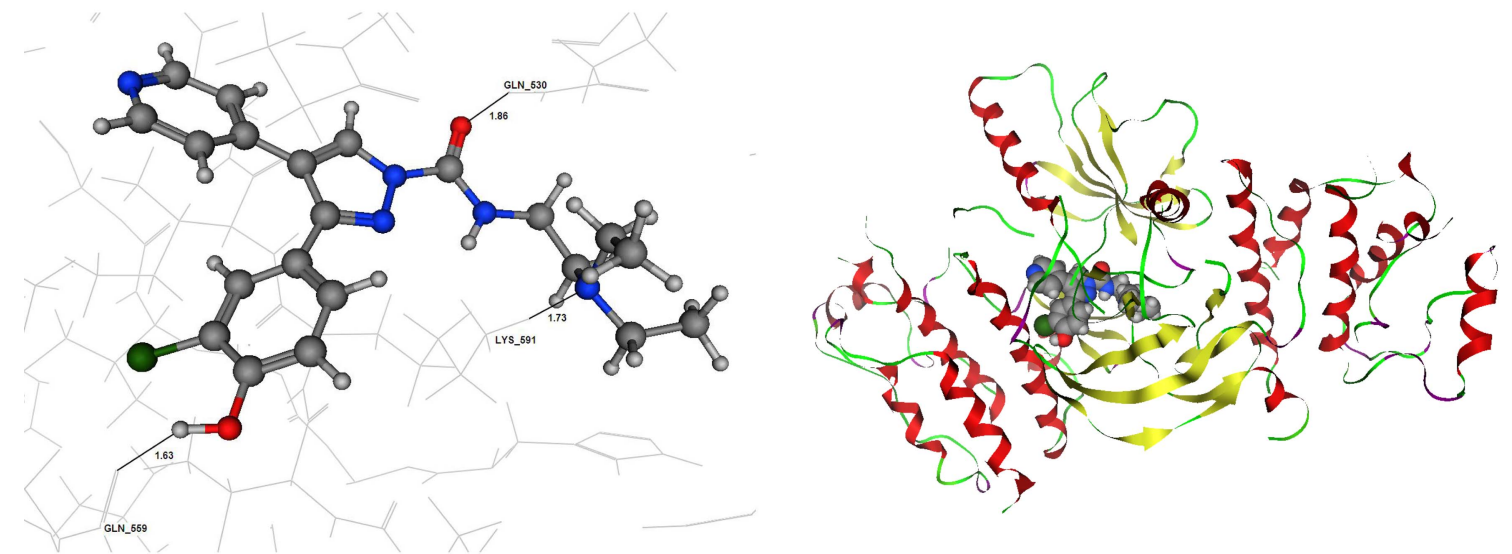

Figure 3. Interaction between compound IIb and V600E-b-Raf, hydrogen bonds are shown as black lines (left panel). The ligand IIb (space filling) is embedded into the kinase domain (right panel).

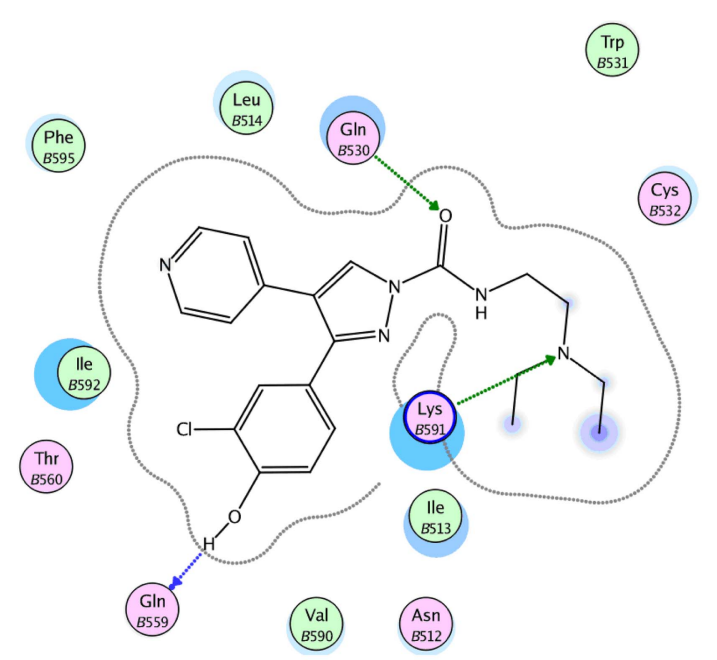

Figure 4. 2D-presentation for the binding interactions of compound IIb with V600E-b-Raf kinase domain.

Bioscience, Billerica, MA, USA). Unless otherwise noted, all solvents and reagents were commercially available and used without further purification.

3-Chloro-4-methoxybenzoic Acid (2): A mixture of 3,4dichlorobenzoic acid (1, $2.0 \mathrm{~g}, 10.4 \mathrm{mmol})$ and $\mathrm{NaOMe}$ $(6.74 \mathrm{~mL}, 25 \mathrm{wt} \%$ solution in methanol, $31.2 \mathrm{mmol})$ in HMPA $(40 \mathrm{~mL})$ was heated at $120{ }^{\circ} \mathrm{C}$ for $15 \mathrm{~h}$. The mixture was poured into ice-water and acidified with conc. $\mathrm{HCl}$ to give 3-chloro-4-methoxybenzoic acid (2, $1.56 \mathrm{~g}, 80 \%)$ as a precipitate which was filtered, washed with water, dried, and used in the next step without further purification. ${ }^{1} \mathrm{H}-\mathrm{NMR}$ $\left(\mathrm{CD}_{3} \mathrm{OD}\right) \delta 3.98(\mathrm{~s}, 3 \mathrm{H}), 7.17(\mathrm{~d}, 1 \mathrm{H}, J=8.4 \mathrm{~Hz}), 7.96-8.01$ $(\mathrm{m}, 2 \mathrm{H})$.

Methyl 3-Chloro-4-methoxybenzoate (3): Acetyl chloride $(1.9 \mathrm{~mL}, 28.1 \mathrm{mmol})$ was added dropwise to a solution of 2 $(1.0 \mathrm{~g}, 5.4 \mathrm{mmol})$ in $\mathrm{MeOH}(40 \mathrm{~mL})$ at $0{ }^{\circ} \mathrm{C}$ and the reaction mixture was then stirred at room temperature for $15 \mathrm{~h}$. After evaporation of the organic solvent, the residue was purified by flash column chromatography (silica gel, hexane-methylene chloride $5: 1 \mathrm{v} / \mathrm{v}$ then switching to hexane-methylene chloride $1: 1 \mathrm{v} / \mathrm{v})$ to give $3(0.75 \mathrm{~g}, 70 \%)$. mp $89-90{ }^{\circ} \mathrm{C} ;{ }^{1} \mathrm{H}-$
$\operatorname{NMR}\left(\mathrm{CDCl}_{3}\right) \delta 3.80-3.97(\mathrm{~m}, 6 \mathrm{H}), 6.95(\mathrm{~d}, 1 \mathrm{H}, J=8.6 \mathrm{~Hz})$, $7.20(\mathrm{dd}, 1 \mathrm{H}, J=2.0 \mathrm{~Hz}, J=8.2 \mathrm{~Hz}), 7.95(\mathrm{~d}, 1 \mathrm{H}, J=2.1$ $\mathrm{Hz})$.

1-(3-Chloro-4-methoxyphenyl)-2-(pyridin-4-yl)ethanone (4): To a mixture of compound $3(1.0 \mathrm{~g}, 5.0 \mathrm{mmol})$ and 4 picoline $(0.5 \mathrm{~mL}, 5.6 \mathrm{mmol})$ in THF $(5 \mathrm{~mL})$ in a water bath at $-25{ }^{\circ} \mathrm{C}$, LHMDS $(3.7 \mathrm{~mL}, 1.0 \mathrm{M}$ solution in THF, 19.9 mmol) was slowly added to maintain the temperature at $-25{ }^{\circ} \mathrm{C}$. The resulting mixture was stirred overnight at room temperature. The mixture was quenched with saturated aqueous $\mathrm{NH}_{4} \mathrm{Cl}$. Ethyl acetate $(10 \mathrm{~mL})$ was added and the organic layer was separated. The aqueous layer was extracted with ethyl acetate $(3 \times 10 \mathrm{~mL})$. The combined organic layer extracts were washed with brine and dried over anhydrous $\mathrm{Na}_{2} \mathrm{SO}_{4}$. The organic solvent was evaporated under reduced pressure and the residue was purified by flash column chromatography (silica gel, hexane-ethyl acetate 1:1 $\mathrm{v} / \mathrm{v}$ then switching to hexane-ethyl acetate $1: 5 \mathrm{v} / \mathrm{v}$ ) to yield compound 4 (0.65 g, 50\%). mp 124-126 ${ }^{\circ} \mathrm{C}$; ${ }^{1} \mathrm{H}-\mathrm{NMR}$ (DMSO$\left.d_{6}\right) \delta 3.96(\mathrm{~s}, 3 \mathrm{H}), 4.45(\mathrm{~s}, 2 \mathrm{H}), 7.27-7.32(\mathrm{~m}, 3 \mathrm{H}), 8.04-8.08$ (m, 2H), $8.50(\mathrm{~d}, 2 \mathrm{H}, J=5.0 \mathrm{~Hz})$.

4-[3-(3-Chloro-4-methoxyphenyl)-1H-pyrazol-4-yl]pyridine (5): Compound $4(1.0 \mathrm{~g}, 3.8 \mathrm{mmol})$ was added to DMFDMA $(5.14 \mathrm{~mL}, 38.2 \mathrm{mmol})$ and the mixture was stirred at room temperature for $18 \mathrm{~h}$. The resulting solution was concentrated to dryness to furnish an oil, which was used in the next step without purification. To a portion of the oil from the previous step $(0.137 \mathrm{~g}, 0.457 \mathrm{mmol})$ in $\mathrm{EtOH}(3 \mathrm{~mL})$ was added hydrazine monohydrate $(0.04 \mathrm{~mL}, 0.76 \mathrm{mmol})$ and the reaction mixture was stirred overnight at room temperature. Water $(5 \mathrm{~mL})$ was added to the reaction mixture and the organics were extracted with ethyl acetate $(3 \times 5 \mathrm{~mL})$. The combined organic layer extracts were washed with brine and dried over anhydrous $\mathrm{Na}_{2} \mathrm{SO}_{4}$. After evaporation of the organic solvent, the residue was purified by column chromatography (silica gel, hexane-ethyl acetate 1:1 v/v then switching to hexane-ethyl acetate $1: 5 \mathrm{v} / \mathrm{v}$ ) to yield compound 5 (0.10 g, 74\%). mp 198-201 ${ }^{\circ} \mathrm{C}$; ${ }^{1} \mathrm{H}-\mathrm{NMR}$ (DMSO$\left.d_{6}\right) \delta 3.89(\mathrm{~s}, 3 \mathrm{H}), 7.16-7.50(\mathrm{~m}, 5 \mathrm{H}), 7.91(\mathrm{~s}, 1 \mathrm{H}), 8.47(\mathrm{~d}$, $2 \mathrm{H}, J=4.6 \mathrm{~Hz}$ ), 13.30 (brs, $1 \mathrm{H})$. 
Phenyl 3-(3-Chloro-4-methoxyphenyl)-4-(pyridin-4-yl)1H-pyrazole-1-carboxylate (7): To a solution of compound $5(0.1 \mathrm{~g}, 0.35 \mathrm{mmol})$ in anhydrous THF $(10 \mathrm{~mL})$, triethylamine $(0.112 \mathrm{~g}, 1.1 \mathrm{mmol})$ was slowly added at $0{ }^{\circ} \mathrm{C}$. Phenyl chloroformate $(0.165 \mathrm{~g}, 1.05 \mathrm{mmol})$ was slowly added to the above solution at $0{ }^{\circ} \mathrm{C}$. The reaction mixture was stirred at the same temperature for $2 \mathrm{~h}$. The mixture was diluted with $\mathrm{H}_{2} \mathrm{O}(10 \mathrm{~mL})$ and $\mathrm{CH}_{2} \mathrm{Cl}_{2}(15 \mathrm{~mL})$. The organic layer was separated and the aqueous layer was extracted with $\mathrm{CH}_{2} \mathrm{Cl}_{2}$ $(3 \times 15 \mathrm{~mL})$. The combined organic layer extractes were washed with brine, and dried over anhydrous $\mathrm{MgSO}_{4}$. The organic solvent was evaporated under reduced pressure and the residue (a mixture of compounds 6 and 7) was used in the next step without further purification.

General Procedure for Preparation of Compounds Ia-i. To a solution of the crude product of the previous step $(0.1 \mathrm{~g}$, $0.246 \mathrm{mmol})$ in dry $\mathrm{CH}_{2} \mathrm{Cl}_{2}(3 \mathrm{~mL})$, a solution of the appropriate ethanamine derivative $(0.738 \mathrm{mmol})$ in dry $\mathrm{CH}_{2} \mathrm{Cl}_{2}$ ( $2 \mathrm{~mL})$, and anhydrous $\mathrm{K}_{2} \mathrm{CO}_{3}(68 \mathrm{mg}, 0.492 \mathrm{mmol})$ were added. The reaction mixture was stirred at room temperature for $1 \mathrm{~h}$. Water $(5 \mathrm{~mL})$ was added to the reaction mixture and the organic layer was separated. The aqueous layer was extracted with $\mathrm{CH}_{2} \mathrm{Cl}_{2}(2 \times 3 \mathrm{~mL})$ and the combined organic layer extracts were washed with brine and dried over anhydrous $\mathrm{MgSO}_{4}$. The organic solvent was evaporated under reduced pressure and the residue was obtained.

3-(3-Chloro-4-methoxyphenyl)- $N$-(2-(dimethylamino)ethyl)4-(pyridin-4-yl)-1H-pyrazole-1-carboxamide (Ia): It was purified by flash column chromatography (silica gel, ethyl acetate then switching to ethyl acetate-methanol 4:1 v/v). Yield $16 \%$; mp 52-53 ${ }^{\circ} \mathrm{C}$; IR (KBr) $\left[\mathrm{cm}^{-1}\right]$ 3437, 2968, 2844, $1693,1604,1543,1510,1465,1419,1290,1268,1221$, 1187, 1066; ${ }^{1} \mathrm{H}-\mathrm{NMR}\left(\mathrm{CD}_{3} \mathrm{OD}\right) \delta 2.34(\mathrm{~s}, 6 \mathrm{H}), 2.65$ (t, 2H, $J$ $=5.5 \mathrm{~Hz}), 3.56(\mathrm{t}, 2 \mathrm{H}, J=5.5 \mathrm{~Hz}), 3.92(\mathrm{~s}, 3 \mathrm{H}), 6.91(\mathrm{~d}, 1 \mathrm{H}, J$ $=8.4 \mathrm{~Hz}), 7.21-7.28(\mathrm{~m}, 2 \mathrm{H}), 7.59(\mathrm{~d}, 2 \mathrm{H}, J=4.5 \mathrm{~Hz}), 8.58$ $(\mathrm{d}, 2 \mathrm{H}, J=4.6 \mathrm{~Hz}), 8.62$ (s, $1 \mathrm{H})$; $\mathrm{MS} m / z 400.9\left[\mathrm{M}+\mathrm{H}^{+}\right]$.

3-(3-Chloro-4-methoxyphenyl)- $\mathrm{N}$-(2-(diethylamino)ethyl)4-(pyridin-4-yl)-1H-pyrazole-1-carboxamide (Ib): It was purified by flash column chromatography (silica gel, ethyl acetate then switching to ethyl acetate-methanol 6:1 v/v). Yield 50\%; mp 130-131 ${ }^{\circ} \mathrm{C}$; IR (KBr) $\left[\mathrm{cm}^{-1}\right]$ 3440, 3000, 2937, 1729, 1603, 1543, 1522, 1478, 1410, 1262, 1220, 1140, 1059; ${ }^{1} \mathrm{H}-\mathrm{NMR}$ (DMSO- $d_{6}$ ) $\delta 0.99$ (t, $6 \mathrm{H}, J=6.5 \mathrm{~Hz}$ ), $2.48(\mathrm{q}, 4 \mathrm{H}, J=6.4 \mathrm{~Hz}), 2.62(\mathrm{t}, 2 \mathrm{H}, J=5.7 \mathrm{~Hz}), 3.14(\mathrm{t}$, $2 \mathrm{H}, J=5.5 \mathrm{~Hz}), 3.90(\mathrm{~s}, 3 \mathrm{H}), 6.92(\mathrm{~d}, 1 \mathrm{H}, J=8.6 \mathrm{~Hz}), 7.13-$ $7.23(\mathrm{~m}, 2 \mathrm{H}), 7.58$ (d, 2H, $J=4.4 \mathrm{~Hz}), 8.51$ (brs, 1H), 8.56 $(\mathrm{d}, 2 \mathrm{H}, J=4.3 \mathrm{~Hz}), 8.66$ (s, 1H); MS $m / z 429.1\left[\mathrm{M}+\mathrm{H}^{+}\right]$.

3-(3-Chloro-4-methoxyphenyl)- $\mathrm{N}$-(2-morpholinoethyl)4-(pyridin-4-yl)-1H-pyrazole-1-carboxamide (Ic): It was purified by flash column chromatography (silica gel, ethyl acetate then switching to ethyl acetate-methanol $4: 1 \mathrm{v} / \mathrm{v}$ ). Yield 74\%; mp 128-130 ${ }^{\circ} \mathrm{C}$; IR (KBr) $\left[\mathrm{cm}^{-1}\right] 3351,2954$, $2811,1732,1609,1506,1451,1268,1170,1119,1066 ;{ }^{1} \mathrm{H}-$ NMR (DMSO- $\left.d_{6}\right) \delta 2.44-2.50(\mathrm{~m}, 6 \mathrm{H}), 3.24(\mathrm{t}, 2 \mathrm{H}, J=4.7 \mathrm{~Hz})$, $3.57(\mathrm{t}, 4 \mathrm{H}, J=4.1 \mathrm{~Hz}), 3.89(\mathrm{~s}, 3 \mathrm{H}), 7.19(\mathrm{~d}, 1 \mathrm{H}, J=8.6 \mathrm{~Hz})$, $7.31-7.35(\mathrm{~m}, 2 \mathrm{H}), 7.63(\mathrm{~d}, 2 \mathrm{H}, J=5.9 \mathrm{~Hz}), 8.54(\mathrm{~d}, 2 \mathrm{H}, J=$ $6.0 \mathrm{~Hz}), 8.58$ (brs, 1H), 8.72 (s, 1H); MS $m / z 443.0\left[\mathrm{M}+\mathrm{H}^{+}\right]$.
3-(3-Chloro-4-methoxyphenyl)- $\mathrm{N}$-(2-(2,6-dimethylmorpholino) ethyl)-4-(pyridin-4-yl)-1H-pyrazole-1-carboxamide (Id): It was purified by flash column chromatography (silica gel, ethyl acetate). Yield 38\%; mp 105-106 ${ }^{\circ} \mathrm{C}$; ${ }^{1} \mathrm{H}-\mathrm{NMR}$ $\left(\mathrm{CDCl}_{3}\right) \delta 1.18(\mathrm{~d}, 6 \mathrm{H}, J=6.2 \mathrm{~Hz}), 2.60-2.80(\mathrm{~m}, 6 \mathrm{H}), 3.56$ $(\mathrm{t}, 2 \mathrm{H}, J=5.6 \mathrm{~Hz}), 3.70-3.74(\mathrm{~m}, 2 \mathrm{H}), 3.94(\mathrm{~s}, 3 \mathrm{H}), 6.90(\mathrm{~d}$, $1 \mathrm{H}, J=8.5 \mathrm{~Hz}), 7.20-7.27$ (m, 2H), 7.63 (d, 2H, $J=4.4 \mathrm{~Hz})$, $8.41(\mathrm{~s}, 1 \mathrm{H}), 8.57(\mathrm{~d}, 2 \mathrm{H}, J=4.2 \mathrm{~Hz}) ;{ }^{13} \mathrm{C}-\mathrm{NMR}\left(\mathrm{CDCl}_{3}\right) \delta$ $155.6,150.2,149.3,142.5,139.8,130.2,128.8,128.0$, $124.8,122.9,121.4,120.7,111.8,71.8,59.2,56.5,56.2$, 36.9, 19.1; $\mathrm{MS} m / z$ 471.0 [M+ $\left.\mathrm{H}^{+}\right]$.

3-(3-Chloro-4-methoxyphenyl)- $\mathrm{N}$-(2-(4-methylpiperazin-1yl)ethyl)-4-(pyridin-4-yl)-1H-pyrazole-1-carboxamide (Ie): It was purified by flash column chromatography (silica gel, ethyl acetate). Yield 40\%; mp 127-128 ${ }^{\circ} \mathrm{C}$; IR (KBr) [cm $\left.{ }^{-1}\right]$ 3354, 3089, 2938, 1728, 1607, 1578, 1455, 1355, 1291, 1257, 1085, 1004; ${ }^{1} \mathrm{H}-\mathrm{NMR}$ (DMSO-d $) \delta 2.27$ (s, 3H), 2.35-2.55 (m, 8H), $2.63(\mathrm{t}, 2 \mathrm{H}, J=6.1 \mathrm{~Hz}), 2.98(\mathrm{t}, 2 \mathrm{H}, J=$ $6.0 \mathrm{~Hz}), 3.90(\mathrm{~s}, 3 \mathrm{H}), 6.91(\mathrm{~d}, 1 \mathrm{H}, J=8.2 \mathrm{~Hz}), 7.18-7.26(\mathrm{~m}$, $2 \mathrm{H}), 7.43(\mathrm{~d}, 2 \mathrm{H}, J=4.4 \mathrm{~Hz}), 8.22(\mathrm{~s}, 1 \mathrm{H}), 8.48$ (d, 2H, $J=$ $4.5 \mathrm{~Hz})$; $\mathrm{MS} m / z 455.9\left[\mathrm{M}+\mathrm{H}^{+}\right]$.

$\mathrm{N}$-(2-(4-Acetylpiperazin-1-yl)ethyl)-3-(3-chloro-4-methoxyphenyl)-4-(pyridin-4-yl)-1H-pyrazole-1-carboxamide (If): It was purified by flash column chromatography (silica gel, ethyl acetate then switching to ethyl acetate-methanol 4:1 v/v). Yield 22\%; mp 183-186 ${ }^{\circ} \mathrm{C}$; IR $(\mathrm{KBr})\left[\mathrm{cm}^{-1}\right] 3355$, 3096, 2946, 1722, 1704, 1605, 1512, 1439, 1419, 1290, $1267,1065,1060,1009 ;{ }^{1} \mathrm{H}-\mathrm{NMR}\left(\mathrm{CD}_{3} \mathrm{OD}\right) \delta 2.10(\mathrm{~s}, 3 \mathrm{H})$, 2.54-2.63 (m, 6H), $3.30(\mathrm{t}, 2 \mathrm{H}, J=5.1 \mathrm{~Hz}), 3.51(\mathrm{t}, 4 \mathrm{H}, J=$ $4.0 \mathrm{~Hz}), 3.92(\mathrm{~s}, 3 \mathrm{H}), 6.89(\mathrm{~d}, 1 \mathrm{H}, J=8.2 \mathrm{~Hz}), 7.14-7.25(\mathrm{~m}$, $2 \mathrm{H}), 7.62(\mathrm{~d}, 2 \mathrm{H}, J=4.3 \mathrm{~Hz}), 8.40(\mathrm{~s}, 1 \mathrm{H}), 8.55$ (d, 2H, $J=$ $4.2 \mathrm{~Hz})$; $\mathrm{MS} m / z 484.0\left[\mathrm{M}+\mathrm{H}^{+}\right]$.

3-(3-Chloro-4-methoxyphenyl)- $\mathrm{N}$-(2-(piperidin-1-yl)ethyl)4-(pyridin-4-yl)-1H-pyrazole-1-carboxamide (Ig): It was purified by flash column chromatography (silica gel, ethyl acetate). Yield $80 \%$; mp 40-42 ${ }^{\circ} \mathrm{C}$; IR $(\mathrm{KBr})\left[\mathrm{cm}^{-1}\right] 3355$, 2937, 1722, 1606, 1580, 1500, 1456, 1352, 1258, 1156, 1130, 1090, 1044; ${ }^{1} \mathrm{H}-\mathrm{NMR}$ (DMSO- $\left.d_{6}\right) \delta 1.35-1.46(\mathrm{~m}$, $6 \mathrm{H}), 2.28(\mathrm{t}, 4 \mathrm{H}, J=6.8 \mathrm{~Hz}), 2.54(\mathrm{t}, 2 \mathrm{H}, J=6.2 \mathrm{~Hz}), 3.07$ (t, $2 \mathrm{H}, J=6.1 \mathrm{~Hz}), 3.89(\mathrm{~s}, 3 \mathrm{H}), 6.89(\mathrm{~d}, 1 \mathrm{H}, J=8.4 \mathrm{~Hz}), 7.26-$ $7.36(\mathrm{~m}, 4 \mathrm{H}), 8.46(\mathrm{~s}, 1 \mathrm{H}), 8.52(\mathrm{~d}, 2 \mathrm{H}, J=4.8 \mathrm{~Hz})$; MS $m / z$ $440.95\left[\mathrm{M}+\mathrm{H}^{+}\right]$.

3-(3-Chloro-4-methoxyphenyl)- $\mathrm{N}$-(2-(2-methylpiperidin-1yl)ethyl)-4-(pyridin-4-yl)-1H-pyrazole-1-carboxamide (Ih): It was purified by flash column chromatography (silica gel, ethyl acetate). Yield 48\%; mp 48-50 ${ }^{\circ} \mathrm{C}$; IR (KBr) $\left[\mathrm{cm}^{-1}\right]$ 3356, 3123, 2933, 1728, 1607, 1514, 1449, 1341, 1282, 1140, 1063, 1025; ${ }^{1} \mathrm{H}-\mathrm{NMR}\left(\mathrm{CDCl}_{3}\right) \delta 1.11(\mathrm{~d}, 3 \mathrm{H}, J=5.2$ $\mathrm{Hz}), 1.35-1.67$ (m, 6H), 2.27-2.53 (m, 5H), 3.50 (t, 2H, $J=$ $5.0 \mathrm{~Hz}), 3.94(\mathrm{~s}, 3 \mathrm{H}), 6.89(\mathrm{~d}, 1 \mathrm{H}, J=8.5 \mathrm{~Hz}), 7.21-7.35(\mathrm{~m}$, 2H), 7.65 (d, 2H, $J=4.3 \mathrm{~Hz}), 8.39(\mathrm{~s}, 1 \mathrm{H}), 8.57$ (d, 2H, $J=$ $4.4 \mathrm{~Hz}) ;{ }^{13} \mathrm{C}-\mathrm{NMR}\left(\mathrm{CDCl}_{3}\right) \delta 155.6,150.2,149.3,142.9$, 138.7, 130.2, 128.8, 128.0, 125.2, 123.0, 121.7, 120.5, 111.8, $56.2,56.1,52.1,51.8,37.6,34.4,26.1,23.5,18.7$; MS m/z $455.07\left[\mathrm{M}+\mathrm{H}^{+}\right]$.

3-(3-Chloro-4-methoxyphenyl)-4-(pyridin-4-yl)- $\mathrm{N}$-(2-(pyrrolidin-1-yl)ethyl)-1H-pyrazole-1-carboxamide (Ii): It was 
purified by flash column chromatography (silica gel, ethyl acetate then switching to ethyl acetate-methanol 3:1 v/v). Yield 66\%; mp 125-127 ${ }^{\circ} \mathrm{C}$; IR (KBr) $\left[\mathrm{cm}^{-1}\right]$ 3297, 3148, 2947, 1731, 1601, 1510, 1452, 1342, 1280, 1265, 1148, 1067, 1030; ${ }^{1} \mathrm{H}-\mathrm{NMR}\left(\mathrm{CD}_{3} \mathrm{OD}\right) \delta 1.82(\mathrm{t}, 4 \mathrm{H}, J=5.3 \mathrm{~Hz})$, $2.62(\mathrm{t}, 4 \mathrm{H}, J=5.0 \mathrm{~Hz}), 2.76(\mathrm{t}, 2 \mathrm{H}, J=6.0 \mathrm{~Hz}), 3.33(\mathrm{t}, 2 \mathrm{H}$, $J=6.1 \mathrm{~Hz}), 3.93(\mathrm{~s}, 3 \mathrm{H}), 6.89(\mathrm{~d}, 1 \mathrm{H}, J=8.3 \mathrm{~Hz}), 7.18-7.28$ $(\mathrm{m}, 2 \mathrm{H}), 7.62(\mathrm{~d}, 2 \mathrm{H}, J=4.5 \mathrm{~Hz}), 8.43(\mathrm{~s}, 1 \mathrm{H}), 8.58(\mathrm{~d}, 2 \mathrm{H}$, $J=4.4 \mathrm{~Hz}) ;{ }^{13} \mathrm{C}-\mathrm{NMR}\left(\mathrm{CD}_{3} \mathrm{OD}\right) \delta 154.3,150.3,149.0$, $142.9,138.5,129.8,128.9,128.2,124.9,123.3,121.4$, $120.1,111.9,55.3,55.1,53.7,38.7,22.8 ; \mathrm{MS} m / z 426.93$ [M $\left.+\mathrm{H}^{+}\right]$.

General Procedure for Preparation of Compounds IIai. To a mixture of compound Ia-i $(0.1 \mathrm{mmol})$ in methylene chloride $(3 \mathrm{~mL}), \mathrm{BF}_{3} \cdot \mathrm{Me}_{2} \mathrm{~S}(0.13 \mathrm{~g}, 1.0 \mathrm{mmol})$ was added dropwise at room temperature under $\mathrm{N}_{2}$ and the reaction mixture was stirred at the same temperature for $48 \mathrm{~h}$. The mixture was quenched with saturated aqueous $\mathrm{NaHCO}_{3}$ until effervescence ceased. Ethyl acetate $(3 \mathrm{~mL})$ was added and the organic layer was separated. The aqueous layer was extracted with ethyl acetate $(3 \times 3 \mathrm{~mL})$. The combined organic layer extracts were washed with brine and dried over anhydrous $\mathrm{Na}_{2} \mathrm{SO}_{4}$. The organic solvent was evaporated under reduced pressure and the residue was obtained.

3-(3-Chloro-4-hydroxyphenyl)- $\mathrm{N}$-(2-(dimethylamino)ethyl)4-(pyridin-4-yl)-1H-pyrazole-1-carboxamide (IIa): It was purified by flash column chromatography (silica gel, ethyl acetate then switching to ethyl acetate-methanol 4:1 v/v). Yield 38\%; mp 198-201 ${ }^{\circ} \mathrm{C}$; IR (KBr) $\left[\mathrm{cm}^{-1}\right]$ 3392, 3126, 2972, 2923, 1730, 1610, 1594, 1514, 1415, 1345, 1295, 1204, 1153, 1004; ${ }^{1} \mathrm{H}-\mathrm{NMR}\left(\mathrm{CD}_{3} \mathrm{OD}\right) \delta 2.38(\mathrm{~s}, 6 \mathrm{H}), 2.67$ (t, $2 \mathrm{H}, J=5.7 \mathrm{~Hz}), 3.58(\mathrm{t}, 2 \mathrm{H}, J=5.5 \mathrm{~Hz}), 6.86(\mathrm{~d}, 1 \mathrm{H}, J=$ $8.4 \mathrm{~Hz}), 7.21-7.31(\mathrm{~m}, 2 \mathrm{H}), 7.51(\mathrm{~d}, 2 \mathrm{H}, J=4.5 \mathrm{~Hz}), 8.54$ (d, $2 \mathrm{H}, J=4.6 \mathrm{~Hz}), 8.65(\mathrm{~s}, 1 \mathrm{H})$; $\mathrm{MS} m / z 386.95\left[\mathrm{M}+\mathrm{H}^{+}\right]$.

3-(3-Chloro-4-hydroxyphenyl)- $N$-(2-(diethylamino)ethyl)4-(pyridin-4-yl)-1H-pyrazole-1-carboxamide (IIb): It was purified by flash column chromatography (silica gel, ethyl acetate then switching to ethyl acetate-methanol 6:1 v/v). Yield 57\%; mp 145-147 ${ }^{\circ} \mathrm{C}$; IR (KBr) $\left[\mathrm{cm}^{-1}\right]$ 3393, 3127, 2970, 1729, 1614, 1595, 1513, 1417, 1344, 1295, 1205, 1155, 1004; ${ }^{1} \mathrm{H}-\mathrm{NMR}\left(\mathrm{CD}_{3} \mathrm{OD}\right) \delta 1.14(\mathrm{t}, 6 \mathrm{H}, J=6.8 \mathrm{~Hz})$, $2.75(\mathrm{q}, 4 \mathrm{H}, J=6.7 \mathrm{~Hz}), 2.86(\mathrm{t}, 2 \mathrm{H}, J=7.0 \mathrm{~Hz}), 3.54(\mathrm{t}, 2 \mathrm{H}$, $J=6.8 \mathrm{~Hz}), 6.88(\mathrm{~d}, 1 \mathrm{H}, J=8.4 \mathrm{~Hz}), 7.14-7.25(\mathrm{~m}, 2 \mathrm{H})$, $7.48(\mathrm{~d}, 2 \mathrm{H}, J=4.6 \mathrm{~Hz}), 8.53(\mathrm{~d}, 2 \mathrm{H}, J=4.4 \mathrm{~Hz}), 8.65$ (s, $1 \mathrm{H})$; MS $m / z 414.96\left[\mathrm{M}+\mathrm{H}^{+}\right]$.

3-(3-Chloro-4-hydroxyphenyl)- $\mathrm{N}$-(2-morpholinoethyl)4-(pyridin-4-yl)-1H-pyrazole-1-carboxamide (IIc): It was purified by flash column chromatography (silica gel, ethyl acetate then switching to ethyl acetate-methanol 5:1 v/v). Yield 40\%; mp $>300{ }^{\circ} \mathrm{C}$; IR (KBr) $\left[\mathrm{cm}^{-1}\right] 3438,3127,2934$, 1732, 1610, 1496, 1414, 1350, 1297, 1118, 1087; ${ }^{1} \mathrm{H}-\mathrm{NMR}$ $\left(\mathrm{DMSO}-d_{6}\right) \delta 2.50-2.64(\mathrm{~m}, 6 \mathrm{H}), 3.34-3.57(\mathrm{~m}, 6 \mathrm{H}), 6.80(\mathrm{~d}$, $1 \mathrm{H}, J=8.7 \mathrm{~Hz}), 7.20-7.33(\mathrm{~m}, 2 \mathrm{H}), 7.48(\mathrm{~d}, 2 \mathrm{H}, J=6.4 \mathrm{~Hz})$, $8.52(\mathrm{~d}, 2 \mathrm{H}, J=6.4 \mathrm{~Hz}), 8.69(\mathrm{~s}, 1 \mathrm{H})$; MS $m / z 428.83[\mathrm{M}+$ $\left.\mathrm{H}^{+}\right]$.

3-(3-Chloro-4-hydroxyphenyl)- $N$-(2-(2,6-dimethylmorpholino)ethyl)-4-(pyridin-4-yl)-1 $H$-pyrazole-1-carboxamide
(IId): It was purified by flash column chromatography (silica gel, ethyl acetate then switching to ethyl acetatemethanol 10:1 v/v). Yield 63\%; mp 179-181 ${ }^{\circ} \mathrm{C}$; IR (KBr) $\left[\mathrm{cm}^{-1}\right]$ 3395, 3127, 2932, 1738, 1614, 1593, 1510, 1407, 1322, 1292, 1154, 1096, 1006, ${ }^{1} \mathrm{H}-\mathrm{NMR}\left(\mathrm{CD}_{3} \mathrm{OD}\right) \delta 1.20(\mathrm{~d}$, $6 \mathrm{H}, J=6.1 \mathrm{~Hz}), 2.52-2.71(\mathrm{~m}, 6 \mathrm{H}), 3.34(\mathrm{t}, 2 \mathrm{H}, J=5.5 \mathrm{~Hz})$, 3.74-3.77 (m, 2H), $6.88(\mathrm{~d}, 1 \mathrm{H}, J=8.4 \mathrm{~Hz}), 7.15-7.23(\mathrm{~m}$, 2H), 7.55 (d, 2H, $J=4.5 \mathrm{~Hz}), 8.43(\mathrm{~d}, 2 \mathrm{H}, J=4.4 \mathrm{~Hz}), 8.51$ (s, 1H); MS $m / z 456.97\left[\mathrm{M}+\mathrm{H}^{+}\right]$.

3-(3-Chloro-4-hydroxyphenyl)- $N$-(2-(4-methylpiperazin1-yl)ethyl)-4-(pyridin-4-yl)-1H-pyrazole-1-carboxamide (IIe): It was purified by flash column chromatography (silica gel, ethyl acetate). Yield 50\%; mp 138-141 ${ }^{\circ} \mathrm{C}$; IR (KBr) $\left[\mathrm{cm}^{-1}\right]$ 3402, 3128, 2972, 1737, 1610, 1592, 1510, 1406, 1352, 1299, 1154, 1094, 1004; ${ }^{1} \mathrm{H}-\mathrm{NMR}$ (DMSO- $d_{6}$ ) $\delta$ $2.25(\mathrm{~s}, 3 \mathrm{H}), 2.42-2.50(\mathrm{~m}, 8 \mathrm{H}), 2.60(\mathrm{t}, 2 \mathrm{H}, J=6.1 \mathrm{~Hz})$, $3.00(\mathrm{t}, 2 \mathrm{H}, J=6.0 \mathrm{~Hz}), 6.88(\mathrm{~d}, 1 \mathrm{H}, J=8.4 \mathrm{~Hz}), 7.14-7.24$ $(\mathrm{m}, 2 \mathrm{H}), 7.51(\mathrm{~d}, 2 \mathrm{H}, J=4.3 \mathrm{~Hz}), 8.12$ (brs, $1 \mathrm{H}), 8.45$ (d, $2 \mathrm{H}, J=4.5 \mathrm{~Hz}), 8.58(\mathrm{~s}, 1 \mathrm{H})$; MS $m / z 441.95\left[\mathrm{M}+\mathrm{H}^{+}\right]$.

$\mathrm{N}$-(2-(4-Acetylpiperazin-1-yl)ethyl)-3-(3-chloro-4-hydroxyphenyl)-4-(pyridin-4-yl)-1H-pyrazole-1-carboxamide (IIf): It was purified by flash column chromatography (silica gel, ethyl acetate then switching to ethyl acetate-methanol 4:1 v/v). Yield 58\%; mp 193-195 ${ }^{\circ} \mathrm{C}$; IR (KBr) $\left[\mathrm{cm}^{-1}\right] 3349,3125$, 2934, 1730, 1613, 1511, 1433, 1346, 1157, 1001; ${ }^{1} \mathrm{H}-\mathrm{NMR}$ $\left(\mathrm{CD}_{3} \mathrm{OD}\right) \delta 2.06(\mathrm{~s}, 3 \mathrm{H}), 2.53-2.62(\mathrm{~m}, 6 \mathrm{H}), 2.97(\mathrm{t}, 2 \mathrm{H}, J=$ $4.1 \mathrm{~Hz}), 3.43(\mathrm{t}, 4 \mathrm{H}, J=4.0 \mathrm{~Hz}), 6.87(\mathrm{~d}, 1 \mathrm{H}, J=8.4 \mathrm{~Hz})$, 7.10-7.21 (m, 2H), $7.36(\mathrm{~d}, 2 \mathrm{H}, J=4.5 \mathrm{~Hz}), 8.13(\mathrm{~s}, 1 \mathrm{H})$, $8.58(\mathrm{~d}, 2 \mathrm{H}, J=4.6 \mathrm{~Hz}) ; \mathrm{MS} m / z 470.0\left[\mathrm{M}+\mathrm{H}^{+}\right]$.

3-(3-Chloro-4-hydroxyphenyl)- $\mathrm{N}$-(2-(piperidin-1-yl)ethyl)4-(pyridin-4-yl)-1H-pyrazole-1-carboxamide (IIg): It was purified by flash column chromatography (silica gel, ethyl acetate). Yield $60 \% ; \mathrm{mp} 215-217^{\circ} \mathrm{C}$; IR (KBr) $\left[\mathrm{cm}^{-1}\right] 3418$, 2933, 1728, 1610, 1512, 1433, 1348, 1154, 1001; ${ }^{1} \mathrm{H}-\mathrm{NMR}$ (CD $\mathrm{CD}) \delta 1.50-1.58(\mathrm{~m}, 6 \mathrm{H}), 2.20(\mathrm{t}, 4 \mathrm{H}, J=7.2 \mathrm{~Hz}), 2.61$ (t, 2H, $J=7.8 \mathrm{~Hz}), 3.26(\mathrm{t}, 2 \mathrm{H}, J=7.7 \mathrm{~Hz}), 6.84(\mathrm{~d}, 1 \mathrm{H}, J=$ $8.0 \mathrm{~Hz}), 7.03-7.10(\mathrm{~m}, 2 \mathrm{H}), 7.56(\mathrm{~d}, 2 \mathrm{H}, J=5.0 \mathrm{~Hz}), 7.99-$ $8.50(\mathrm{~m}, 3 \mathrm{H}) ; \mathrm{MS} m / z 426.95\left[\mathrm{M}+\mathrm{H}^{+}\right]$.

3-(3-Chloro-4-hydroxyphenyl)- $\mathrm{N}$-(2-(2-methylpiperidin-1yl)ethyl)-4-(pyridin-4-yl)-1 $\boldsymbol{H}$-pyrazole-1-carboxamide (IIh): It was purified by flash column chromatography (silica gel, ethyl acetate then switching to ethyl acetate-methanol 4:1 v/v). Yield 46\%; mp 141-142 ${ }^{\circ} \mathrm{C}$; IR (KBr) $\left[\mathrm{cm}^{-1}\right] 3409$, 2935, 1731, 1613, 1510, 1436, 1344, 1154, 1002; ${ }^{1} \mathrm{H}-\mathrm{NMR}$ $\left(\mathrm{CD}_{3} \mathrm{OD}\right) \delta 1.20(\mathrm{~d}, 3 \mathrm{H}, J=6.0 \mathrm{~Hz}), 1.32-1.65(\mathrm{~m}, 6 \mathrm{H})$, 2.43-2.71 (m, 5H), $3.08(\mathrm{t}, 2 \mathrm{H}, J=5.1 \mathrm{~Hz}), 6.84(\mathrm{~d}, 1 \mathrm{H}, J=$ $8.4 \mathrm{~Hz}), 7.08-7.14(\mathrm{~m}, 2 \mathrm{H}), 7.42(\mathrm{~d}, 2 \mathrm{H}, J=4.6 \mathrm{~Hz}), 8.52(\mathrm{~d}$, $2 \mathrm{H}, J=4.7 \mathrm{~Hz}), 8.62(\mathrm{~s}, 1 \mathrm{H})$; $\mathrm{MS} m / z 441.0\left[\mathrm{M}+\mathrm{H}^{+}\right]$.

3-(3-Chloro-4-hydroxyphenyl)-4-(pyridin-4-yl)- $\mathrm{N}$-(2-(pyrrolidin-1-yl)ethyl)-1H-pyrazole-1-carboxamide (IIi): It was purified by flash column chromatography (silica gel, ethyl acetate then switching to ethyl acetate-methanol 2:1 v/v). Yield 54\%; mp 201-203 ${ }^{\circ} \mathrm{C}$; IR (KBr) $\left[\mathrm{cm}^{-1}\right]$ 3440, 3123, 2928, 2793, 1733, 1609, 1497, 1405, 1348, 1299, 1257, 1087; ${ }^{1} \mathrm{H}-\mathrm{NMR}\left(\mathrm{DMSO}-d_{6}\right) \delta 1.72(\mathrm{t}, 4 \mathrm{H}, J=5.2 \mathrm{~Hz}), 2.27$ $(\mathrm{t}, 4 \mathrm{H}, J=5.1 \mathrm{~Hz}), 2.62(\mathrm{t}, 2 \mathrm{H}, J=6.1 \mathrm{~Hz}), 3.01(\mathrm{t}, 2 \mathrm{H}, J=$ $6.0 \mathrm{~Hz}), 6.82(\mathrm{~d}, 1 \mathrm{H}, J=8.5 \mathrm{~Hz}), 7.06(\mathrm{dd}, 1 \mathrm{H}, J=8.4 \mathrm{~Hz}, J$ 
$=2.0 \mathrm{~Hz}), 7.34(\mathrm{~d}, 2 \mathrm{H}, J=6.0 \mathrm{~Hz}), 7.44(\mathrm{~d}, 1 \mathrm{H}, J=1.9 \mathrm{~Hz})$, 8.52 (d, 2H, $J=5.9 \mathrm{~Hz}), 8.67(\mathrm{~s}, 1 \mathrm{H}) ; \mathrm{MS} m / z 412.85[\mathrm{M}+$ $\left.\mathrm{H}^{+}\right]$.

Evaluation of the Biological Activity. A375P cells were purchased from American Type Culture Collection (ATCC, Rockville, MD, USA) and maintained in Dulbecco's modified eagle medium (DMEM, Welgene, Daegu, Korea) supplemented with $10 \%$ foetal bovine serum (FBS, Welgene, Daegu, Korea) and 1\% penicillin/streptomycin (Welgene, Daegu, Korea) in a humidified atmosphere with $5 \% \mathrm{CO}_{2}$ at $37^{\circ} \mathrm{C}$. A375P cells were taken from culture substrate with $0.05 \%$ trypsin- $0.02 \%$ EDTA and plated at a density of $5 \times$ $10^{3}$ cells/well in 96 well plates and then incubated at $37{ }^{\circ} \mathrm{C}$ for $24 \mathrm{~h}$ in a humidified atmosphere with $5 \% \mathrm{CO}_{2}$ prior to treatment with various concentrations (3-fold serial dilution, 12 points) of test compounds. The cells were incubated for $48 \mathrm{~h}$ after treatment with the test compounds. The A357P cell viability was assessed by the conventional 3-(4,5dimethylthiazol-2-yl)-2,5-diphenyltetrazolium bromide (MTT) reduction assay. MTT assays were carried out with CellTiter $96^{\circledR}$ (Promega) according to the manufacturer's instructions. The absorbance at $590 \mathrm{~nm}$ was recorded using EnVision 2103 (Perkin Elmer; Boston, MA, USA). The $\mathrm{IC}_{50}$ was calculated using GraphPad Prism 4.0 software.

Molecular Docking Methodology. Docking studies were performed using MOE 2008.10. With this purpose, the crystal structure of V600E-b-Raf Kinase was obtained from Protein Data Bank ${ }^{27}$ (PDB ID: 3OG7) in order to prepare the protein for docking study. Docking procedure was followed using the standard protocol implemented in MOE 2008.10 and the geometry of resulting complex was studied using the MOE's pose viewer utility.

Acknowledgments. We'd like to thank the Chemical Computing Group Inc, 1010 Sherbrooke Street West, Suite 910, Montreal, H3A 2R7, Canada, for its valuable agreement to use the package of MOE 2008.10 software. We are also grateful to Korea Institute of Science and Technology (KIST) for financial support.

\section{References}

1. Barth, A.; Wanek, L. A.; Morton, D. L. J. Am. Coll. Surg. 1995, 181, 193.

2. Atallah, E.; Flaherty, L. Curr. Treat. Options Oncol. 2005, 6, 185.
3. Anderson, C. M.; Buzaid, A. C.; Legha, S. S. Oncol. (Williston Park) 1995, 9, 1149.

4. Gray-Schopfer, V.; Wellbrock, C.; Marais, R. Nature 2007, 445, 851.

5. Garbe, C.; Eigentler, T. K. Melanoma Res. 2007, 17, 117.

6. Koon, H. B.; Atkins, M. B. Expert Rev. Anticancer Ther. 2007, 7, 79.

7. Lawson, D. H. Cancer Control 2005, 12, 236.

8. Rosenburg, S. A.; Lotze, M. T.; Yang, J. C.; Aebersold, P. M.; Linehan, W. M.; Seipp, C. A.; White, D. E. Ann. Surg. 1989, 210, 474.

9. Atkins, M. B.; Lotze, M. T.; Dutcher, J. P.; Fisher, R. I.; Weiss, G.; Margolin, K.; Abrams, J.; Sznol, M.; Parkinson, D.; Hawkins, M.; Paradise, C.; Kunkel, L.; Rosenberg, S. A. J. Clin. Oncol. 1999, 17, 2105.

10. Strumberg, D.; Voliotis, D.; Moeller, J. G.; Hilger, R. A.; Richly, H.; Kredtke, S.; Beling, C.; Scheulen, M. E.; Seeber, S. J. Clin. Pharmacol. Ther. 2002, 40, 580.

11. Richly, H.; Kupsh, P.; Passage, K.; Grubert, M.; Hilger, R. A.; Voigtmann, R.; Schwartz, B.; Brendel, E.; Christensen, O.; Haase, C. G.; Strumberg, D. Int. J. Clin. Pharmacol. Ther. 2004, 42, 650.

12. Wilhelm, S. M.; Carter, C.; Tang, L.; Wilkie, D.; McNabola, A.; Rong, H. Cancer Res. 2004, 64, 7099.

13. Strumberg, D.; Richly, H.; Hilger, R. A.; Schleucher, N.; Korfee, S. J. Clin. Oncol. 2005, 23, 965.

14. Clark, J. W.; Eder, J. P.; Ryan, D.; Lathia, C.; Lenz, H. J. Clin. Cancer Res. 2005, 11, 5472.

15. Moore, M.; Hirte, H. W.; Siu, L.; Oza, A.; Hotte, S. J.; Petrenciuc, O.; Cihon, F.; Lathia, C.; Schwartz, B. Ann. Oncol. 2005, 16, 1688.

16. Egberts, F.; Kaehler, K. C.; Livingstone, E.; Hauschild, A. Onkologie 2008, 31, 398.

17. Wilhelm, S. M.; Adnane, L.; Newell, P.; Villanueva, A.; Llovet, J. M.; Lynch, M. Mol. Cancer Ther. 2008, 7, 3129.

18. Alexandrescu, D. T.; McClure, R.; Farzanmehr, H.; Dasanu, C. A J. Clin. Oncol. 2008, 26, 4047.

19. Bennett, M. J.; Cho-Schultz, S.; Deal, J. G.; King, S. J.; Marrone, T. J.; Palmer, C. L.; Romines, W. H.; Rui, E. Y.; Sutton, S. C.; Zhender, L. R. WO 2007/105058 A2. 2007 [Chem. Abstr. 2007, 147, 385972].

20. Pulici, M.; Zuccotto, F.; Badari, A.; Nuvoloni, S.; Cervi, G.; Traquandi, G.; Biondaro, S.; Trifiro', P.; Marchionni, C.; Modugno, M. WO 2010010154 A1. 2010 [Chem. Abstr. 2010, 115411].

21. Dean, D. K.; Andrew, A. K.; Wilson, D. M. WO 2002094808 A1. 2002 [Chem. Abstr. 2002, 138, 4601].

22. Lipinski, C. A.; Lombardo, F.; Dominy, B. W.; Feeney, P. J. $A d v$. Drug Deliv. Rev. 2001, 46, 3.

23. Clark, D. E.; Pickett, S. D. Drug Discov. Today 2000, 5, 49.

24. Tetko, I. V. Drug Discov. Today 2005, 10, 1497.

25. http://www.organic-chemistry.org/prog/peo.

26. MOE 2008.10 of Chemical Computing Group. Inc.

27. http://www.rcsb.org/pdb.

28. Halgren, T. A. J. Comput. Chem. 1996, 17, 490. 